\title{
Antibacterial Effects of Wood Structural Components and Extractives from Pinus sylvestris and Picea abies on Methicillin-Resistant Staphylococcus aureus and Escherichia coli 0157:H7
}

Tiina Vainio-Kaila, ${ }^{\mathrm{a}, \mathrm{b}, *}$ Xue Zhang, ${ }^{\mathrm{a}}$ Tuomas Hänninen, ${ }^{\mathrm{a}}$ Aino Kyyhkynen, ${ }^{\mathrm{b}}$ Leena-Sisko Johansson, ${ }^{a}$ Stefan Willför, ${ }^{c}$ Monika Österberg, ${ }^{a}$ Anja Siitonen, ${ }^{\mathrm{b}}$ and Lauri Rautkari ${ }^{\mathrm{a}}$

\begin{abstract}
Antibacterial properties of wood structural components and extractives were investigated against methicillin-resistant Staphylococcus aureus (MRSA) and Escherichia coli $\mathrm{O} 157: \mathrm{H} 7$ by placing bacterial inoculum on the model surfaces and incubating them for 2, 4, and $24 \mathrm{~h}$. After incubation, the amount of viable bacteria on the surfaces was studied. The film coverage and thickness were evaluated with atomic-force microscopy (AFM) and X-ray photoelectron spectroscopy (XPS). The extracts were analyzed with gas chromatography-mass spectrometry (GC-MS). The results showed that films fully covered the glass surfaces. The XPS results confirmed the analysis of GC-MS, which revealed more similarities between the extractives of pine heartwood and spruce heartwood than between pine heartwood and pine sapwood. Only the pine heartwood extract showed an antibacterial effect against E. coliO157:H7. In contrast, MRSA was susceptible to all of the extracts and milled wood lignin (MWL).
\end{abstract}

Keywords: Antibacterial wood; MRSA; E. coli; Wood structural components; Extractives; Scots pine; Norway spruce

Contact information: a: Department of Bioproducts and Biosystems, School of Chemical Engineering, Aalto University, P.O. Box 16300, FI-00076 Aalto, Finland; b: Bacterial Infections Unit, National Institute for Health and Welfare (THL), P.O. Box 30, FI-00271 Helsinki, Finland; c: Johan Gadolin Process Chemistry Centre, Laboratory of Wood and Paper Chemistry, Åbo Akademi University, Porthansgatan 3, FI-20500 Åbo, Finland; *Corresponding author: tiina.vainio-kaila@aalto.fi

\section{INTRODUCTION}

Solid Scots pine wood has been shown to have antibacterial properties against several bacterial strains (Koch et al. 2002; Milling et al. 2005a; Milling et al. 2005b; Vainio-Kaila et al. 2011, 2013). In addition, Norway spruce, larch (Kavian-Jahromi et al. 2015), and several hardwoods (Ak et al. 1994; Koch et al. 2002) have antibacterial properties. It has been suggested that the antibacterial properties of wood are a combination of the chemical composition of the wood and the drying effect of the surface of the wood, caused by its porosity (Milling et al. 2005a).

Wood is composed mainly of cellulose, hemicelluloses, lignin, and extractives. The extractives are a large group of different chemical substances. Their composition depends on the wood species and the location in the tree (Willför et al. 2003b,c). Knotwood extracts of Scots pine and several other wood species have both antibacterial and antifungal properties (Lindberg et al. 2004; Välimaa et al. 2007). A limited amount of literature is available on the antibacterial effects of wood extracts. Scots pine heartwood (Laireiter et al. 2013) and sapwood and spruce heartwood (Vainio-Kaila et al. 2015) extracts inhibit the 
growth of several Gram-positive bacterial strains, while pine sapwood extract inhibits a Gram-negative strain. Extracts of Alaska cedar, western juniper, and several North American hardwoods have some antibacterial effects (Omar et al. 2000; Johnston et al. 2001). Several separate compounds such as terpenes (Himejima et al. 1992; Mourey and Canillac 2002), pinosylvins (Välimaa et al. 2007; Plumed-Ferrer et al. 2013), resin acids (Smith et al. 2005), and some fatty acids (Desbois and Smith 2010) have shown antibacterial effects, mostly against Gram-positive bacteria strains. Spruce resin has antimicrobial effects against several bacterial species, including methicillin-resistant Staphylococcus aureus (MRSA) (Rautio et al. 2007).

In addition to extractives, lignins have various positive health effects, including antibacterial properties. Dong et al. (2011) found commercial kraft lignin to have strong antibacterial properties, probably due to its high $\mathrm{pH}$, and lignin extracted from residue of corn stover in ethanol production has also shown antibacterial properties. Lignin from bagasse and cotton stalk pulping has demonstrated antibacterial properties, depending on the cooking conditions (Nada et al. 1989). In addition, phenolic fragments from lignin (Zemek et al. 1979; Baurhoo et al. 2008) and nanolignin on linen fabric (Zimniewska et al. 2008) exhibit antibacterial properties. Milled wood lignin (MWL), which best resembles natural wood lignin, has not been investigated in regard to its antibacterial properties. Cellulose has been modified in various ways to create antibacterial material (Adamopoulos et al. 2007; Roy et al. 2007; Hou et al. 2009), where unmodified cellulose is used as a non-antibacterial control. Hemicelluloses stimulate probiotic bacteria and, hence, indirectly operate against harmful bacteria (Polari et al. 2012; Rajani et al. 2016).

In this study, thin films of MWL, cellulose nanofibrils (CNF), galactoglucomannan (GGM), and extractives of Scots pine (Pinus sylvestris) heartwood and sapwood and Norway spruce (Picea abies) heartwood were prepared, and their antibacterial properties were studied in order to gain further understanding of the roles of the different structural compounds and extractives in the antibacterial properties of wood. MRSA and Escherichia coli $\mathrm{O} 157: \mathrm{H} 7$ were chosen as relevant pathogenic bacterial strains representing Grampositive and Gram-negative strains, respectively. MRSA is one of the strains that hospitals struggle to contain (Hierholzer et al. 1995; Dancer 2008). In day care environments, E. coli O157:H7 has caused outbreaks of severe diarrhea (Reida et al. 1994; Rimhanen-Finne et al. 2014).

\section{EXPERIMENTAL}

\section{Materials}

Wood material for the extracts was obtained from Koskisen Oy sawmill in Järvelä, Finland, within two weeks of kiln drying. The sawn wood was taken from mature logs (about 60 to 100 years old). The Scots pine (Pinus sylvestris L.) sapwood and heartwood samples were selected based on the visible color difference between sapwood and heartwood. Norway spruce (Picea abies (L.) H. Karst.) heartwood samples were taken approximately $5 \mathrm{~cm}$ from the pith. Wood material was milled with a Wiley mill to a particle size of $<1 \mathrm{~mm}$. After milling, the wood dust was stored at $-20{ }^{\circ} \mathrm{C}$ until use. Particles were extracted with acetone using a Soxhlet apparatus for $6 \mathrm{~h}$. The concentration of the remaining solution was determined by weighing and drying a small amount, and the solution was heated to $40{ }^{\circ} \mathrm{C}$ to evaporate excess acetone until a concentration of $5.4 \mathrm{~g} / \mathrm{L}$ was reached. Gas chromatography-mass spectrometry (GC-MS) was performed as 
described by Willför et al. (2003c) to determine the total amount (mg/g dry weight) of each extractive component.

The chemical composition of lignin is highly dependent on the lignin source and extraction method. Milled wood lignin is the closest to native lignin (Nunn et al. 1985) and was thus used as the lignin model substrate. The MWL was prepared from spruce sawdust according to Björkman (1956).

Cellulose nanofibrils were obtained from never-dried kraft birch pulp from a Finnish pulp mill by mechanical fibrillation using a Microfluidics M-110Y high-pressure fluidizer (Microfluidics Int. Corp., Westwood, MA). No chemical or enzymatic treatments were applied to the pulp prior to fluidizing it using 12 passes.

Galactoglucomannan was extracted from spruce thermomechanical pulp by hot water extraction followed by a purification process (Willför et al. 2003a).

Polystyrene (PS, average molecular weight about 280,000 g/mol), toluene, and polyethyleneimine (PEI) of analytical grade were purchased from Sigma-Aldrich (St. Louis, MO), and 1,4-dioxane (analytical standard) and acetone (ACS reagent) were purchased from VWR International (Radnor, PA).

\section{Bacterial Strains}

The bacterial strains used were MRSA (ATCC 43300) and E. coli O157:H7, without the stx genes (RHE5402). Prior to use, both strains were subcultured at least twice on sheep blood (MRSA) or Drigalski-Conradi (E. coli) agar plates. The plates were incubated at $37{ }^{\circ} \mathrm{C}$ overnight in ambient atmosphere. Bacterial colonies were moved directly from the agar to physiological $\mathrm{NaCl}$ solution, and their concentration was adjusted to $0.5 \mathrm{McF}$ arland using a photometer (Gene-Trak Systems, Hopkinton, MA). This was equivalent to a concentration of $1.5 \times 10^{8}$ (colony forming units per milliliter $(\mathrm{CFU} / \mathrm{mL}$ ) and was further diluted in physiological $\mathrm{NaCl}$ solution to correspond to a concentration of $1.5 \times 10^{7} \mathrm{CFU} / \mathrm{mL}$.

\section{Preparation of Single Wood Component Substrates}

The CNF films were prepared by spin-coating a CNF dispersion onto a glass surface previously coated with PEI to enhance the CNF adsorption, as previously described (ValleDelgado et al. 2016). First, $40 \mu \mathrm{L} 2.5 \mathrm{mg} / \mathrm{mL}$ PEI solution was dropped on the glass cylinder. After 10 min adsorption, the glass cylinder was rinsed with water and dried with nitrogen gas. The CNF dispersion was then spin-coated atop the PEI film by sonicating a $1.35 \mathrm{~g} / \mathrm{L} \mathrm{CNF}$ dispersion at $25 \%$ amplitude for $1 \mathrm{~min}$, without heating, with a Branson sonifier S-450 D (Branson Corp., Danbury, CT) and then centrifuged to remove the large fibril bundles at $8000 \mathrm{~g}$ (where $\mathrm{g}$ is the relative centrifugal force) for $30 \mathrm{~min}$ at $20{ }^{\circ} \mathrm{C}$ with an Eppendorf centrifuge 5804R (Eppendorf AG, Hamburg, Germany).

The hemicellulose substrates were prepared by dropping $80 \mu \mathrm{L}$ of a $2.5 \% \mathrm{wt}$. aqueous GGM solution atop CNF films prepared as described above. The substrate was immediately dried in an oven at $50{ }^{\circ} \mathrm{C}$ for $30 \mathrm{~min}$.

Polystyrene-coated glass surfaces were used as substrates for the preparation of lignin and extractive films, with $0.5 \mathrm{wt}$.\% PS solution in toluene spin coated onto the glass surfaces in three steps: firstly, at $300 \mathrm{rpm}$ for $3 \mathrm{~s}$ with an acceleration of $500 \mathrm{rpm} / \mathrm{s}$; secondly, at $1000 \mathrm{rpm}$ for $5 \mathrm{~s}$ with an acceleration of $800 \mathrm{rpm} / \mathrm{s}$; and, finally, at $2000 \mathrm{rpm}$ for $30 \mathrm{~s}$ with an acceleration of $800 \mathrm{rpm} / \mathrm{s}$.

Milled wood lignin films were obtained by spin coating $0.5 \mathrm{wt} . \%$ MWL solution in 1,4-dioxane onto PS-coated glass surfaces in three steps (Tammelin et al. 2006): firstly, at 
$400 \mathrm{rpm}$ for $3 \mathrm{~s}$ with an acceleration of $2400 \mathrm{rpm} / \mathrm{s}$; secondly, at $500 \mathrm{rpm}$ for $5 \mathrm{~s}$ with an acceleration of $6000 \mathrm{rpm} / \mathrm{s}$; and, finally, at $1000 \mathrm{rpm}$ for $2 \mathrm{~min}$ with acceleration of 4000 $\mathrm{rpm} / \mathrm{s}$. The procedure was repeated four times to get full MWL coverage.

Extractive films were prepared by spreading $40 \mu \mathrm{L}$ of 5.4 wt. $\%$ extractive solution onto PS-coated glass surfaces and drying at $50{ }^{\circ} \mathrm{C}$ for $5 \mathrm{~min}$. This process was repeated four times for each extractive in order to achieve full coverage.

\section{Atomic-Force Microscopy (AFM)}

A MultiMode 8 atomic force microscope equipped with a NanoScope V controller (Bruker Corporation, Billerica, MA) was used to obtain high resolution images of the films. Images in at least three different spots of each film were obtained in tapping mode in air using NCHV-A probes (Bruker) with a tip radius around $10 \mathrm{~nm}$. Research NanoScope 8.15 software (Bruker) was used for image analysis. The only image correction applied was flattening. The films were scratched and scanned with a scan size of $30 \mu \mathrm{m} \times 30 \mu \mathrm{m}$ at 6 different positions in order to estimate each film's thickness.

\section{X-ray Photoelectron Spectroscopy (XPS)}

A Kratos Analytical AXIS Ultra electron spectrometer (Manchester, UK) was used to analyze the chemical compositions and evaluate the coverages of the extractive films on PS substrate. A monochromated A1 K $\alpha$ X-ray source at $100 \mathrm{~W}$ was applied. A spin-coated neat PS film was measured as a reference. Furthermore, a pure cellulose specimen was measured with each sample batch, as an in situ reference for the experimental conditions in ultra-high vacuum. Low resolution survey spectra and high resolution spectra of O1s and $\mathrm{C} 1$ s regions were collected at several positions across the sample. For the $\mathrm{C} 1 \mathrm{~s}$ region, CasaXPS software (ver 2.3.17.PR1.1) and a four-Gaussian component fit tailored for lignocelluloses were used (Johansson and Campbell 2004).

\section{Cultivations}

Bacterial testing was made by cultivating the bacterial strains on glass cylinders coated with the test materials. The cylinders were placed in empty Petri dishes, and $20 \mu \mathrm{L}$ of bacterial solution was pipetted on top. Clean glass surfaces were used as an inert control. After incubation at room temperature for 2, 4, and 24 hours, the cylinders were placed in test tubes with $7.5 \mathrm{~mL}$ of physiologic $\mathrm{NaCl}$ solution and shaken vigorously, and $200 \mu \mathrm{L}$ from the solution and a 1:10 dilution was spread on sheep blood or Drigalski-Conradi agar plates. After overnight incubation at $37{ }^{\circ} \mathrm{C}$, the $\mathrm{CFUs}$ on the plates were counted. The bacterial cultivations were performed with three parallel samples, and the averages and standard variations were calculated.

\section{RESULTS AND DISCUSSION}

\section{Extractive Composition}

The most abundant compound groups detected in GC-MS analysis were resin acids in the spruce and pine heartwood and triglycerides in the pine sapwood (Table 1). In general, the results agree well with earlier reports on pine and spruce extracts (MartínezIñigo et al. 1999; Hovelstad et al. 2006). Triglycerides were the largest group in the extract of pine sapwood, but Martínez-Iñigo et al. (1999) found resin acids to be the largest group. 
Some differences can be expected as the amount of different substances varies even within the heartwood of a single tree (Ekeberg et al. 2006).

Table 1. Wood Extract Components (mg/g dry weight)

\begin{tabular}{|c|c|c|c|}
\hline & Spruce Heartwood & Pine Sapwood & Pine Heartwood \\
\hline Terpenoids & 17 & 2 & 18 \\
\hline Fatty acids & 109 & 19 & 232 \\
\hline Stilbenes & nd & nd & 174 \\
\hline Resin acids & 141 & 133 & 290 \\
\hline Hydroxy resin acids & 6 & 12 & 9 \\
\hline Lignans & 129 & nd & nd \\
\hline Sterols & 28 & 5 & 5 \\
\hline Monosaccharides & 27 & 4 & 35 \\
\hline Steryl esters & 97 & 40 & 34 \\
\hline Diglycerides & 39 & 36 & 26 \\
\hline Triglycerides & 22 & 414 & 3 \\
\hline
\end{tabular}

nd $=$ not detected

\section{Wood Component Substrates}

A typical fibrillary network of CNF is clearly visible both in the $25 \mu \mathrm{m}^{2}$ and the 1 $\mu \mathrm{m}^{2}$ AFM height images (Fig. 1a and 1b).

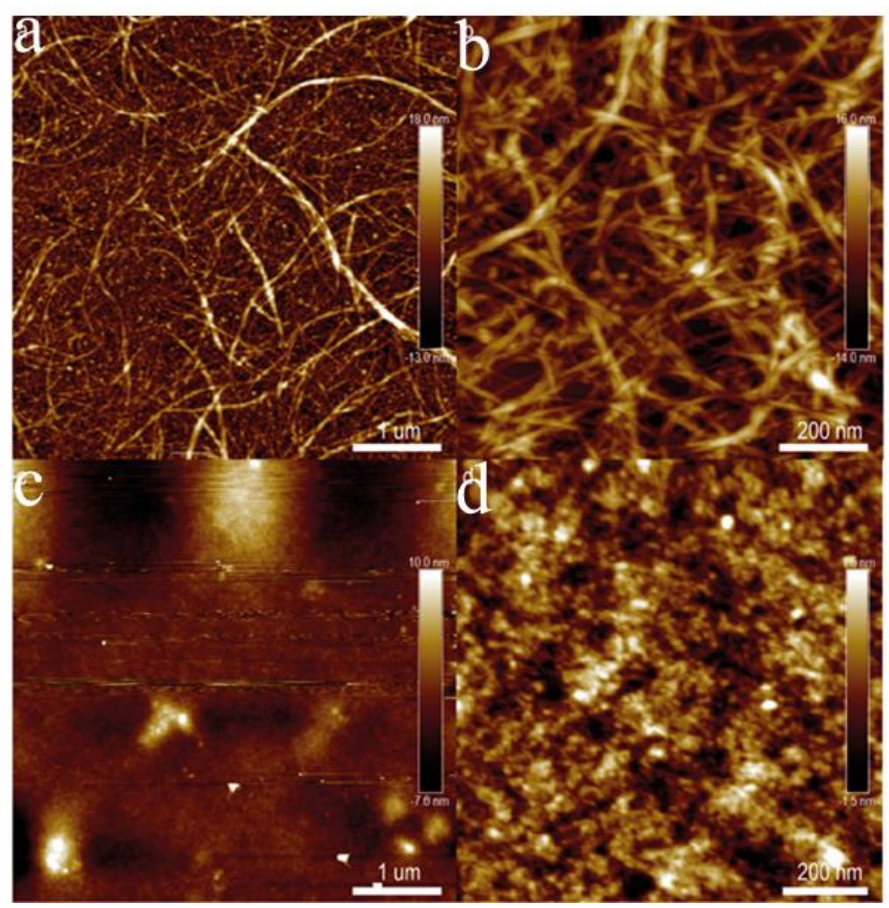

Fig. 1. Atomic-force microscopy height images of spin-coated CNF film with scan sizes of (a) 25 $\mu \mathrm{m}^{2}$ and (b) $1 \mu \mathrm{m}^{2}$ and deposited GGM film with scan sizes of (c) $25 \mu \mathrm{m}^{2}$ and (d) $1 \mu \mathrm{m}^{2}$ 
The fibrils evenly covered the substrate, and no open areas were observed. The AFM height images of GGM deposited on top of CNF substrates (Fig. 1c and 1d) showed that the CNF fibril network could no longer be seen, which indicates that the GGM had fully covered the CNF films with an even film. The average thickness of the film, including GGM, CNF, and PEI, was $36 \pm 1.7 \mathrm{~nm}$. Because the PEI film was 1 to $2 \mathrm{~nm}$ thick and the CNF film about 5 to $8 \mathrm{~nm}$ (Eronen et al. 2011), the GGM film was approximately $26 \mathrm{~nm}$.

The AFM images show that the glass surface (Fig. 2a) was fully covered by PS (Fig. 2b). The spin-coated MWL film (Fig. 2c) appeared to fully cover the PS, and the images were very similar to previously published AFM images of spin-coated MWL films (Tammelin et al. 2006; Salas et al. 2012). The thickness of the MWL layer was $10 \pm 0.46$ nm.
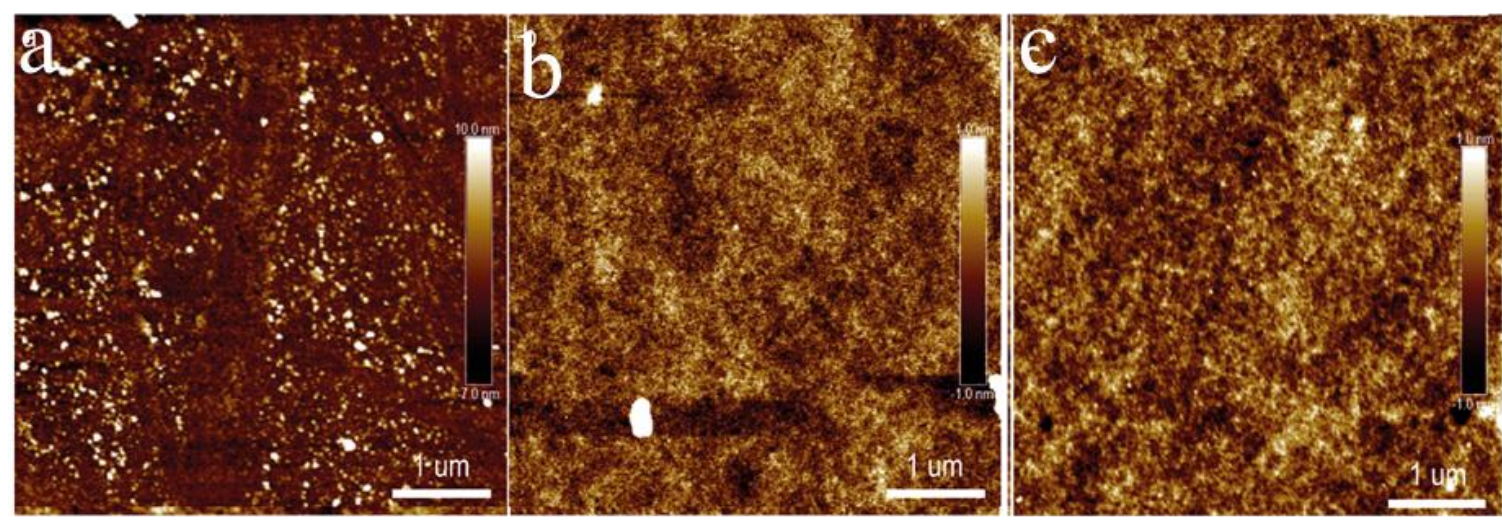

Fig. 2. Atomic-force microscopy height images of (a) glass cylinder surface, (b) PS substrate, and (c) MWL film spin-coated atop the PS substrate

Extractive films were also coated on PS substrates (Fig. 3a and 3b). Due to the presence of a relatively large amount of resin acids, the extractive films were sticky, which made it hard to obtain high resolution topographical images. The pine sapwood was so sticky that no representative image could be obtained.

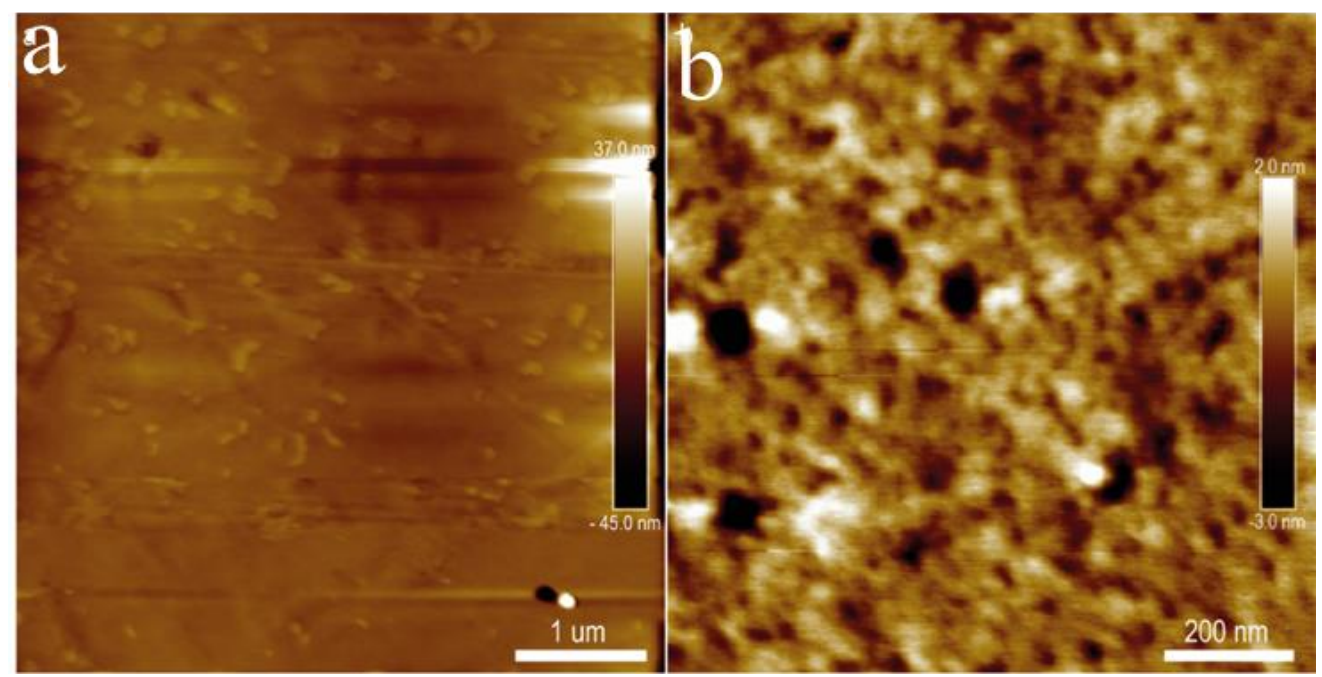

Fig. 3. Atomic-force microscopy height images of extractives deposited on PS-coated glass: (a) pine heartwood, (b) spruce heartwood 
Variation in the compositions of the extractives created very uneven films. Average thicknesses of $229 \pm 40 \mathrm{~nm}, 197 \pm 5 \mathrm{~nm}$, and $175 \pm 59 \mathrm{~nm}$ were obtained for the pine heartwood, pine sapwood, and spruce heartwood, respectively.

X-ray photoelectron spectroscopy measurements were performed on the spincoated extractive films, with the spin-coated, polystyrene-only sample as a reference (Fig. 4). The data for the neat reference was typical of thin, air-exposed polystyrene film. In the survey, only a strong carbon signal with a negligible oxygen trace (due to exposure to ambient air) was observed. Furthermore, the carbon high resolution region showed only aromatic carbon features, namely, a sharp component at $285 \mathrm{eV}$ and a clear plasmonic feature at around $292 \mathrm{eV}$. In contrast, all extractive films showed carbon and oxygen as main components, and both with strong tailing backgrounds, indicating the presence of films thicker than XPS analysis depth (Tougaard 1998). In the high resolution region, the main component was located at $285 \mathrm{eV}$, but it was much broader than in polystyrene and without the plasmonic feature. The results indicated that the substrate polystyrene was well covered by the resin films. Furthermore, XPS high resolution data on carbon $\mathrm{C} 1 \mathrm{~s}$ showed subtle differences in the three resins studied. The two heartwood samples had fairly similar carbon regions, while the sapwood sample was clearly richer in the acidic functionalities, seen as the $290 \mathrm{eV}$ component of the normalized C 1s spectra in Fig. 4 (insert). This result is in agreement with the GC-MS chemical analysis, where more similarities were seen between the two heartwood samples than between the pine heartwood and sapwood samples. The heartwood formation process in the transition zone might explain the similarities between pine and spruce heartwood.

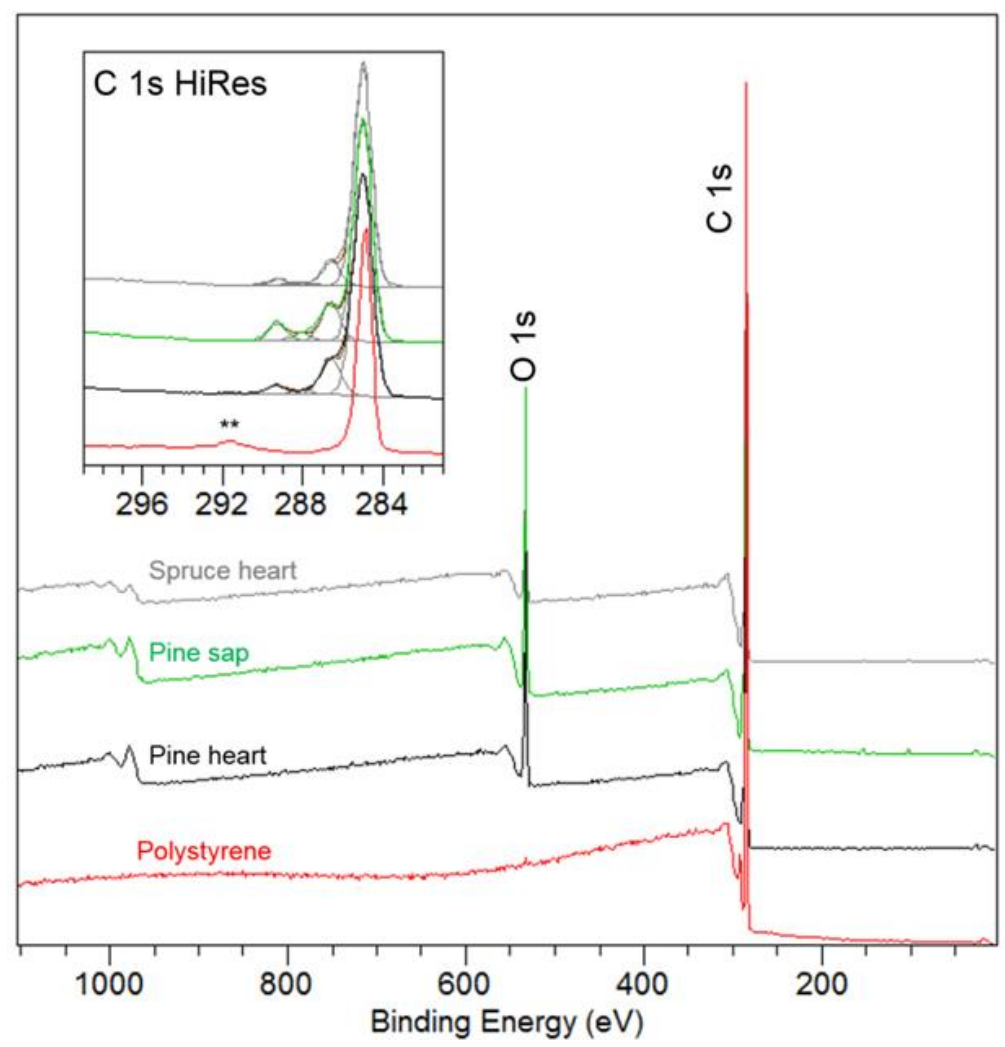

Fig. 4. X-ray photoelectron spectroscopy spectra (survey scans and high resolution $C$ 1s regions) of the spin-coated resin films on polystyrene substrate. Two asterisks $\left({ }^{* *}\right)$ in the insert indicate the plasmonic feature typical of aromatic $C$ is species. This feature was observed on the neat polystyrene surface only. 


\section{Antibacterial Effects}

The only wood component surface shown to suppress the growth of $E$. coli O157:H7 was the extract of pine heartwood (Fig. 5). On the GGM and CNF surfaces, the amount of bacteria decreased at a slower rate than that of the control, which is probably due to the available nutrients in those surfaces. Galactoglucomannan consists of shorter chains and is more easily accessible than CNF, which is paracrystalline. However, hemicelluloses are also available on the CNF. The accessibility leads to GGM being a more readily available source of nutrition for the bacterial cells. Nanofibrillar cellulose is used in hydrogels for growing three-dimensional cell cultures (Bhattacharya et al. 2012; Lou et al. 2013; Liu et al. 2016). Thus, it could be expected not to be very antibacterial. Polystyrene, which was used as an anchoring substrate for both the extractives and the MWL, had a weak antibacterial effect. However, this clearly did not affect the bacterial viability on the films of the extractives and MWL, as MWL and the pine sapwood and spruce heartwood extracts produced no difference relative to the control. As discussed earlier, the films covered the whole surface area.

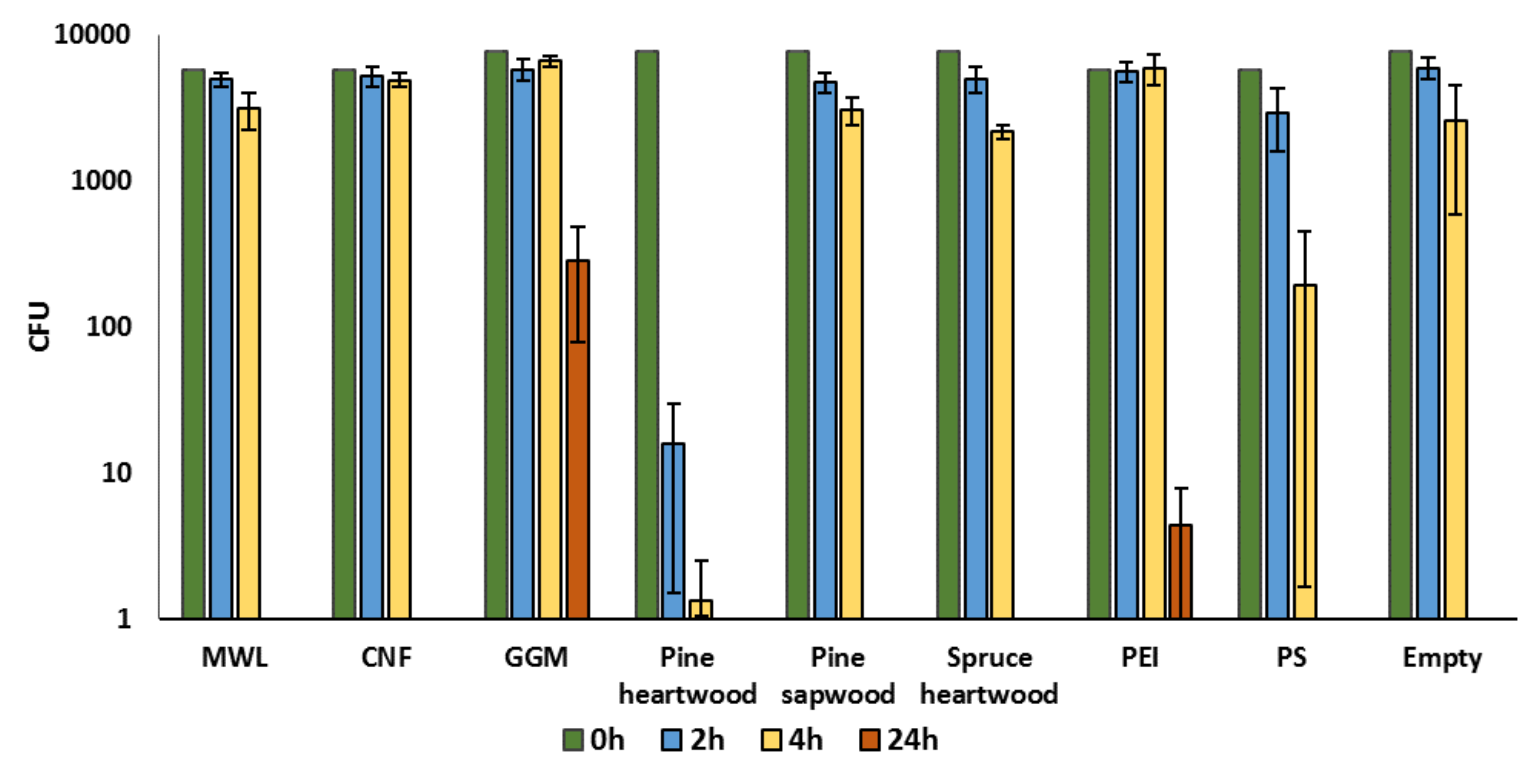

Fig. 5. The amount of colony forming units (CFU) after $0,2,4$, and $24 \mathrm{~h}$ incubation of $E$. coli $\mathrm{H} 157: 07$ on different model surfaces of the structural components of wood, the extractives, and the glues used for preparing the surfaces. Clean glass surface was used as a control.

MRSA was more sensitive to all the extracts studied, pine heartwood being the most effective, followed by spruce heartwood and pine sapwood (Fig. 6); MWL also had an antibacterial effect on MRSA. On the GGM and CNF surfaces, the number of bacteria decreased at a slower rate than that of the control, which is probably due to the available nutrients, as discussed earlier. Neither PEI nor PS had any antibacterial effect on MRSA.

Gram-positive $S$. aureus was more susceptible to wood components than Gramnegative E. coli. This result was similar to several studies on wood components and bacteria (Himejima et al. 1992; Mourey and Canillac 2002; Rautio et al. 2007; Välimaa et al. 2007; Plumed-Ferrer et al. 2013). There are, however, contradictory findings, suggesting that wood or its components would be more effective against Gram-negative strains Klebsiella pneumoniae (Kavian-Jahromi et al. 2015) and E. coli (Schönwälder et al. 2002). When the wood extracts were studied in a broth against these same strains, the 
results were very similar to the present study, as would be expected (Vainio-Kaila et al. 2015). However, the effect of pine sapwood on E. coli was stronger than that of pine heartwood in the broth with the extracts, whereas the results in this study were the opposite. This could depend on the differences in water solubility of the extracts.

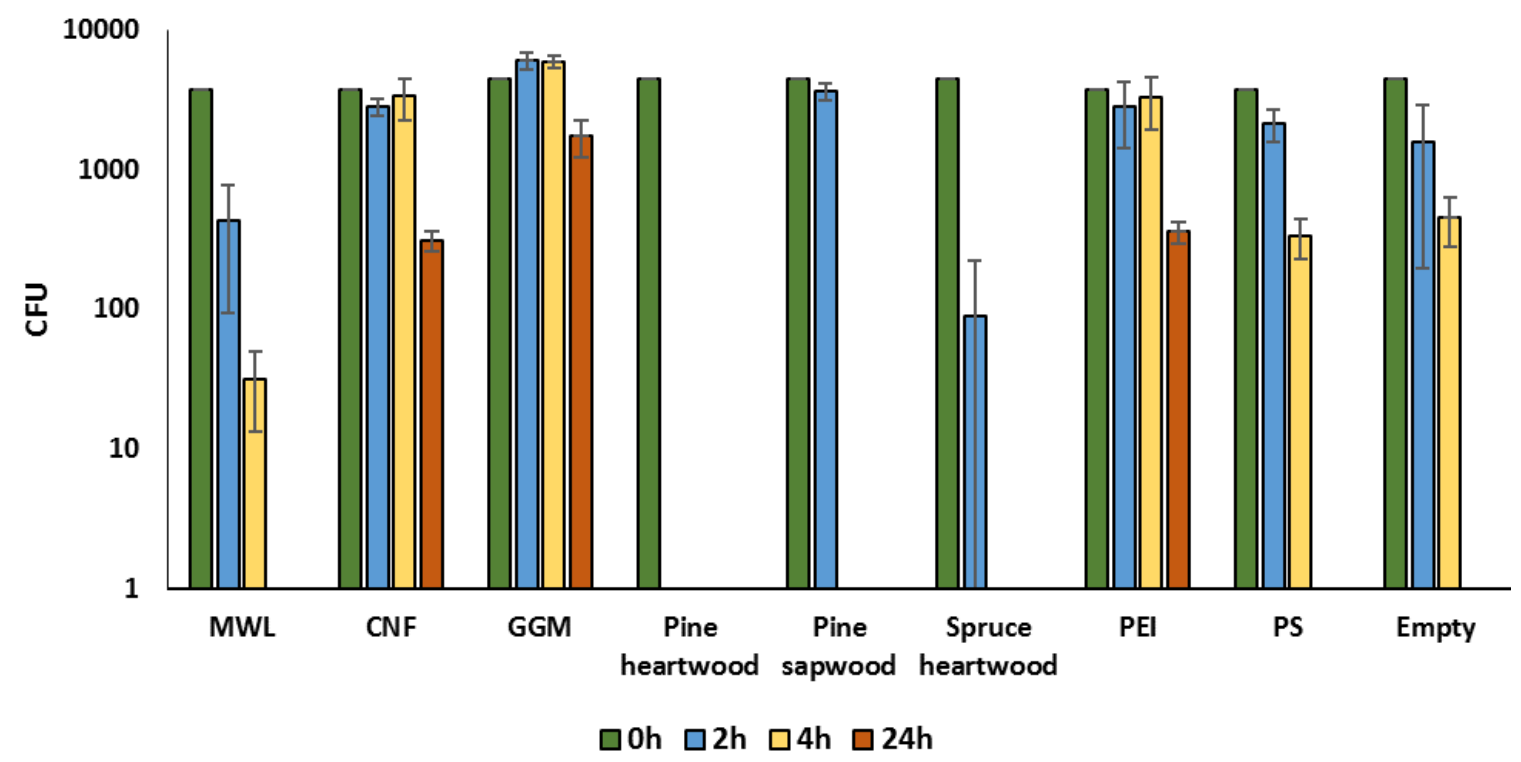

Fig. 6. The amount of colony forming units (CFU) after $0,2,4$, and $24 \mathrm{~h}$ incubation of MRSA on different model surfaces of the structural compounds of wood, the extractives, and the glues used for preparing the surfaces. Clean glass surface was used as a control.

The antibacterial properties of the extracts could originate from various compounds found to have an antibacterial effect, which have been discussed earlier, or from a synergistic effect of several compounds. Some of the most common fatty acids found in all samples (Table 1), such as palmitoleic (C16:1), linoleic (C18:2), and linolenic (C18:3) acids, have been reported to have antibacterial properties (Kabara et al. 1972; Desbois and Smith 2010), though some have been shown to be effective only against Gram-positive strains. Most of the resin acids found in the samples, such as abietic, isopimaric, neoabietic, pimaric, and palustric acid, have been reported to have antibacterial effects (Söderberg et al. 1990; Smith et al. 2005) only against Gram-positive strains. Pine heartwood had the greatest amount of these acids, followed by spruce heartwood, although in spruce heartwood there was more isopimaric acid than in pine heartwood. Stilbenes, pinosylvin, and pinosylvin monomethyl ether exhibiting antibacterial activity (Plumed-Ferrer et al. 2013) were found exclusively in pine heartwood. The chemical composition of the extracts explains the results observed in this study well, as pine heartwood had stronger antibacterial effect than pine sapwood or spruce and it was also found rich in components with demonstrated antibacterial effects.

The antibacterial properties of the wood surface (Milling et al. 2005a,b; VainioKaila et al. 2011, 2013) seem to be affected by several factors. Extractives, as has been shown earlier (Laireiter et al. 2013; Vainio-Kaila et al. 2015), are one of the main factors, but even lignin contributed to these properties. Lignin is more stable on the surface of wood; it does not dissolve as easily as extractives. Its antibacterial effect could therefore be considered more permanent than the effects of the extractives. 
Comparing MWL and the extracts, however, is somewhat complicated. The differences in the thicknesses of the films are notable, and the forms of the materials are different. The extract surfaces were around $200 \mathrm{~nm}$ thick, whereas the MWL surfaces were only $10 \mathrm{~nm}$ thick. Most of the acetone extracts are not water-soluble, but they could affect bacteria in a water-based broth, which means that some active components of the extracts were dissolved in the broth (Vainio-Kaila et al. 2015). However, the MWL covered the whole surface, and its thickness should not affect the results if the effect is purely contactbased and not due to any migration of compounds. These two materials also differ in form, the extracts being softer and stickier and MWL being harder.

\section{CONCLUSIONS}

1. The antibacterial properties of wood are affected by both the extractives and lignin.

2. Pine heartwood had the strongest antibacterial effect of the extracts.

3. Cellulose and hemicellulose surfaces act as nutrition for bacteria.

4. The chemical composition of the surfaces was studied with XPS, which correlated well with the GC-MS results.

\section{REFERENCES CITED}

Adamopoulos, L., Montegna, J., Hampikian, G., Argyropoulos, D. S., Heitmann, J., and Lucia, L. A. (2007). "A simple method to tune the gross antibacterial activity of cellulosic biomaterials," Carbohydr. Polym. 69(4), 805-810. DOI:

10.1016/j.carbpol.2007.02.019

Ak, N. O., Cliver, D. O., and Kaspari, C. W. (1994). "Cutting boards of plastic and wood contaminated experimentally with bacteria," J. Food Prot. 57(1), 16-22. DOI: 10.4315/0362-028X-57.1.16

Baurhoo, B., Ruiz-Feria, C., and Zhao, X. (2008). "Purified lignin: Nutritional and health impacts on farm animals-A review," Anim. Feed Sci. Technol. 144(3), 175-184. DOI: 10.1016/j.anifeedsci.2007.10.016

Bhattacharya, M., Malinen, M. M., Lauren, P., Lou, Y., Kuisma, S. W., Kanninen, L., Lille, M., Corlu, A., GuGuen-Guillouzo, C., and Ikkala, O. (2012). "Nanofibrillar cellulose hydrogel promotes three-dimensional liver cell culture," J. Controlled Release 164(3), 291-298. DOI: 10.1016/j.jconrel.2012.06.039

Björkman, A. (1956). "Studies on finely divided wood. Part 1. Extraction of lignin with neutral solvents," Svensk Papperstidning 59(13), 477-485.

Dancer, S. J. (2008). "Importance of the environment in methicillin-resistant Staphylococcus aureus acquisition: The case for hospital cleaning," The Lancet Infectious Diseases 8(2), 101-113. DOI: 10.1016/S1473-3099(07)70241-4

Desbois, A. P., and Smith, V. J. (2010). "Antibacterial free fatty acids: Activities, mechanisms of action and biotechnological potential," Appl. Microbiol. Biotechnol. 85(6), 1629-1642. DOI: 10.1007/s00253-009-2355-3

Dong, X., Dong, M., Lu, Y., Turley, A., Jin, T., and Wu, C. (2011). "Antimicrobial and antioxidant activities of lignin from residue of corn stover to ethanol production," 
Industrial Crops and Products 34(3), 1629-1634. DOI:

10.1016/j.indcrop.2011.06.002

Ekeberg, D., Flæte, P., Eikenes, M., Fongen, M., and Naess-Andresen, C. F. (2006).

"Qualitative and quantitative determination of extractives in heartwood of Scots pine

(Pinus sylvestris L.) by gas chromatography," Journal of Chromatography A 1109(2), 267-272. DOI: 10.1016/j.chroma.2006.01.027

Eronen, P., Junka, K., Laine, J., and Österberg, M. (2011). "Interaction between water soluble polysaccharides and native nanofibrillar cellulose thin films," BioResources 6(4), 4200-4217.

Hierholzer, W., Garner, J. S., Adams, A. B., Craven, D., Fleming, D., Forlenza, S., Gilchrist, M., Goldmann, D., Larson, E., and Mayhall, C. (1995). "Recommendations for preventing the spread of vancomycin resistance: Recommendations of the Hospital Infection Control Practices Advisory Committee (HICPAC)," Am. J. Infect. Control 23, 87-94. DOI: 10.1016/0196-6553(95)90104-3

Himejima, M., Hobson, K. R., Otsuka, T., Wood, D. L., and Kubo, I. (1992).

"Antimicrobial terpenes from oleoresin of ponderosa pine tree Pinus ponderosa: A defense mechanism against microbial invasion," J. Chem. Ecol. 18(10), 1809-1818. DOI: $10.1007 / \mathrm{BF} 02751105$

Hou, A., Zhou, M., and Wang, X. (2009). "Preparation and characterization of durable antibacterial cellulose biomaterials modified with triazine derivatives," Carbohydr. Polym. 75(2), 328-332. DOI: 10.1016/j.carbpol.2008.07.032

Hovelstad, H., Leirset, I., Oyaas, K., and Fiksdahl, A. (2006). "Screening analyses of pinosylvin stilbenes, resin acids and lignans in Norwegian conifers," Molecules 11(1), 103-114. DOI: 10.3390/11010103

Johansson, L., and Campbell, J. (2004). "Reproducible XPS on biopolymers: Cellulose studies," Surf. Interface Anal. 36(8), 1018-1022. DOI: 10.1002/sia.1827

Johnston, W., Karchesy, J., Constantine, G., and Craig, A. (2001). "Antimicrobial activity of some Pacific Northwest woods against anaerobic bacteria and yeast," Phytotherapy Research 15(7), 586-588. DOI: 10.1002/ptr.765

Kabara, J. J., Swieczkowski, D. M., Conley, A. J., and Truant, J. P. (1972). "Fatty acids and derivatives as antimicrobial agents," Antimicrob. Agents Chemother. 2(1), 23-28. DOI: 10.1128/AAC.2.1.23

Kavian-Jahromi, N., Schagerl, L., Dürschmied, B., Enzinger, S., Schnabl, C., Schnabel, T., and Petutschnigg, A. (2015). "Comparison of the antibacterial effects of sapwood and heartwood of the larch tree focusing on the use in hygiene sensitive areas," European Journal of Wood and Wood Products 73(6), 841-844. DOI: 10.1007/s00107-015-0935-8

Koch, A. P., Kofod, C. J., Konova, D., Kvist, K. E., and Lindegaard, B. (2002). Wood, Plastic and Steel - A Comparison of Hygienic Properties (Part Report No. 10, P 99095), Danish Technological Institute, Høje Taastrup, Denmark.

Laireiter, C. M., Schnabel, T., Köck, A., Stalzer, P., Petutschnigg, A., Oostingh, G. J., and Hell, M. (2013). "Active anti-microbial effects of larch and pine wood on four bacterial strains," BioResources 9(1), 273-281. DOI: 10.15376/biores.9.1.273-281

Lindberg, L. E., Willför, S. M., and Holmbom, B. R. (2004). "Antibacterial effects of knotwood extractives on paper mill bacteria," Journal of Industrial Microbiology and Biotechnology 31(3), 137-147. DOI: 10.1007/s10295-004-0132-y 
Liu, J., Chinga-Carrasco, G., Cheng, F., Xu, W., Willför, S., Syverud, K., and Xu, C. (2016). "Hemicellulose-reinforced nanocellulose hydrogels for wound healing application," Cellulose 23(5), 3129-3143. DOI: 10.1007/s10570-016-1038-3

Lou, Y., Kanninen, L., Kuisma, T., Niklander, J., Noon, L. A., Burks, D., Urtti, A., and Yliperttula, M. (2013). "The use of nanofibrillar cellulose hydrogel as a flexible three-dimensional model to culture human pluripotent stem cells," Stem Cells and Development 23(4), 380-392. DOI: 10.1089/scd.2013.0314

Martínez-Iñigo, M. J., Immerzeel, P., Gutierrez, A., del Río, J. C., and Sierra-Alvarez, R. (1999). "Biodegradability of extractives in sapwood and heartwood from Scots pine by sapstain and white-rot fungi," Holzforschung 53(3), 247-252. DOI:

10.1515/HF.1999.042

Milling, A., Kehr, R., Wulf, A., and Smalla, K. (2005a). "Survival of bacteria on wood and plastic particles: Dependence on wood species and environmental conditions," Holzforschung 59(1), 72-81. DOI: 10.1515/HF.2005.012

Milling, A., Smalla, K., Kehr, R., and Wulf, A. (2005b). "The use of wood in practice-A hygienic risk?" Holz Roh Werkst 63(6), 463-472. DOI: 10.1007/s00107-005-0064-x

Mourey, A., and Canillac, N. (2002). "Anti-Listeria monocytogenes activity of essential oils components of conifers." Food Control 13(4-5), 289-292. DOI: 10.1016/S09567135(02)00026-9

Nada, A., El-Diwany, A., and Elshafei, A. (1989). "Infrared and antimicrobial studies on different lignins," Acta Biotechnol. 9(3), 295-298. DOI: 10.1002/abio.370090322

Nunn, T. R., Howard, J. B., Longwell, J. P., and Peters, W. A. (1985). "Product compositions and kinetics in the rapid pyrolysis of milled wood lignin," Ind. Eng. Chem. Process Des. Dev. 24(3), 844-852. DOI: 10.1021/i200030a053

Omar, S., Lemonnier, B., Jones, N., Ficker, C., Smith, M., Neema, C., Towers, G., Goel, K., and Arnason, J. (2000). "Antimicrobial activity of extracts of eastern North American hardwood trees and relation to traditional medicine," J. Ethnopharmacol. 73(1), 161-170. DOI: 10.1016/S0378-8741(00)00294-4

Plumed-Ferrer, C., Väkeväinen, K., Komulainen, H., Rautiainen, M., Smeds, A., Raitanen, J., Eklund, P., Willför, S., Alakomi, H., and Saarela, M. (2013). "The antimicrobial effects of wood-associated polyphenols on food pathogens and spoilage organisms," Int. J. Food Microbiol. 164(1), 99-107. DOI:

10.1016/j.ijfoodmicro.2013.04.001

Polari, L., Ojansivu, P., Mäkelä, S., Eckerman, C., Holmbom, B., and Salminen, S. (2012). "Galactoglucomannan extracted from spruce (Picea abies) as a carbohydrate source for probiotic bacteria," J. Agric. Food Chem. 60(44), 11037-11043. DOI: 10.1021/jf303741h

Rajani, J., Dastar, B., Samadi, F., Karimi Torshizi, M., Abdulkhani, A., and Esfandyarpour, S. (2016). "Effect of extracted galactoglucomannan oligosaccharides from pine wood (Pinus brutia) on Salmonella Typhimurium colonisation, growth performance and intestinal morphology in broiler chicks," Br. Poult. Sci. 57(5), 682692. DOI: 10.1080/00071668.2016.1200013

Rautio, M., Sipponen, A., Peltola, R., Lohi, J., Jokinen, J., Papp, A., Carlson, P., and Sipponen, P. (2007). "Antibacterial effects of home-made resin salve from Norway spruce (Picea abies)," APMIS 115(4), 335-340. DOI: 10.1111/j.16000463.2007.apm_548.x

Reida, P., Wolff, M., Pöhls, H., Kuhlmann, W., Lehmacher, A., Aleksić, S., Karch, H., and Bockemühl, J. (1994). "An outbreak due to enterohaemorrhagic Escherichia coli 
O157: $\mathrm{H} 7$ in a children day care centre characterized by person-to-person transmission and environmental contamination," Zentralblatt Für Bakteriologie 281(4), 534-543. DOI: 10.1016/S0934-8840(11)80342-7

Rimhanen-Finne, R., Salmenlinna, S., Kyyhkynen, A., and Siitonen, A. (2014). "Enterohaemorrhagic Escherichia coli (EHEC)," in: Infectious Diseases in Finland 2013, S. Jaakola, O. Lyytikäinen, R. Rimhanen-Finne, S. Salmenlinna, C. SavolainenKopra, J. Pirhonen, J. Vuopio, J. Jalava, M. Toropainen, H. Nohynek, et al., (eds.), National Institute for Health and Welfare, Helsinki, Finland.

Roy, D., Knapp, J. S., Guthrie, J. T., and Perrier, S. (2007). "Antibacterial cellulose fiber via RAFT surface graft polymerization," Biomacromolecules 9(1), 91-99. DOI: $10.1021 / \mathrm{bm} 700849 \mathrm{j}$

Salas, C., Rojas, O. J., Lucia, L. A., Hubbe, M. A., and Genzer, J. (2012). "On the surface interactions of proteins with lignin," ACS Applied Materials \& Interfaces 5(1), 199206. DOI: $10.1021 / \mathrm{am} 3024788$

Schönwälder, A., Kehr, R., Wulf, A., and Smalla, K. (2002). "Wooden boards affecting the survival of bacteria?" Holz Roh Werkst. 60(4), 249-257. DOI: 10.1007/s00107002-0300-6

Smith, E., Williamson, E., Zloh, M., and Gibbons, S. (2005). "Isopimaric acid from Pinus nigra shows activity against multidrug-resistant and EMRSA strains of Staphylococcus aureus," Phytotherapy Research 19(6), 538-542. DOI: 10.1002/ptr.1711

Söderberg, T. A., Gref, R., Holm, S., Elmros, T., and Hallmans, G. (1990). "Antibacterial activity of rosin and resin acids in vitro," Scand. J. Plast. Recons. 24(3), 199-205. DOI: $10.3109 / 02844319009041279$

Tammelin, T., Osterberg, M., Johansson, L., and Laine, J. (2006). "Preparation of lignin and extractive model surfaces by using spincoating technique - Application for QCMD studies," Nordic Pulp \& Paper Research Journal 21(4), 444-450. DOI: 10.3183/NPPRJ-2006-21-04-p444-450

Tougaard, S. (1998). "Accuracy of the non-destructive surface nanostructure quantification technique based on analysis of the XPS or AES peak shape," Surf. Interface Anal. 26(4), 249-269. DOI: 10.1002/(SICI)10969918(199804)26:4<249::AID-SIA368>3.3.CO;2-1

Vainio-Kaila, T., Kyyhkynen, A., Rautkari, L., and Siitonen, A. (2015). "Antibacterial effects of extracts of Pinus sylvestris and Picea abies against Staphylococcus aureus, Enterococcus faecalis, Escherichia coli, and Streptococcus pneumoniae," BioResources 10(4), 7763-7771. DOI: 10.15376/biores.10.4.7763-7771

Vainio-Kaila, T., Kyyhkynen, A., Viitaniemi, P., and Siitonen, A. (2011). "Pine heartwood and glass surfaces: Easy method to test the fate of bacterial contamination," European Journal of Wood and Wood Products 69(3), 391-395. DOI: 10.1007/s00107-010-0453-7

Vainio-Kaila, T., Rautkari, L., Nordström, K., Närhi, M., Natri, O., and Kairi, M. (2013). "Effect of extractives and thermal modification on antibacterial properties of Scots pine and Norway spruce," International Wood Products Journal 4(4), 248-252. DOI: 10.1179/2042645313Y.0000000038

Välimaa, A., Honkalampi-Hämäläinen, U., Pietarinen, S., Willför, S., Holmbom, B., and von Wright, A. (2007). "Antimicrobial and cytotoxic knotwood extracts and related pure compounds and their effects on food-associated microorganisms," Int. J. Food Microbiol. 115(2), 235-243. DOI: 10.1016/j.ijfoodmicro.2006.10.031 
Valle-Delgado, J. J., Johansson, L., and Österberg, M. (2016). "Bioinspired lubricating films of cellulose nanofibrils and hyaluronic acid," Colloids and Surfaces B: Biointerfaces 138, 86-93. DOI: 10.1016/j.colsurfb.2015.11.047

Willför, S., Sjöholm, R., Laine, C., Roslund, M., Hemming, J., and Holmbom, B. (2003a). "Characterisation of water-soluble galactoglucomannans from Norway spruce wood and thermomechanical pulp," Carbohydr. Polym. 52(2), 175-187. DOI: 10.1016/S0144-8617(02)00288-6

Willför, S., Hemming, J., Reunanen, M., Eckerman, C., and Holmbom, B. (2003b). "Lignans and lipophilic extractives in Norway spruce knots and stemwood," Holzforschung 57(1), 27-36. DOI: 10.1515/HF.2003.005

Willför, S., Hemming, J., Reunanen, M., and Holmbom, B. (2003c). "Phenolic and lipophilic extractives in Scots pine knots and stemwood," Holzforschung 57(4), 359372. DOI: 10.1515/HF.2003.054

Zemek, J., Košíková, B., Augustin, J., and Joniak, D. (1979). "Antibiotic properties of lignin components," Folia Microbiol. 24(6), 483-486. DOI: 10.1007/BF02927180

Zimniewska, M., Kozłowski, R., and Batog, J. (2008). "Nanolignin modified linen fabric as a multifunctional product," Molecular Crystals and Liquid Crystals 484(1), 409416. DOI: 10.1080/15421400801903395

Article submitted: May 25, 2017; Peer review completed: August 4, 2017; Revised version received and accepted: August 25, 2017; Published: August 31, 2017.

DOI: 10.15376/biores.12.4.7601-7614 